\title{
EVALUASI PELAKSANAAN PENERBITAN KTP-EL PADA DINAS KEPENDUDUKAN DAN PENCATATAN SIPIL KOTA PADANG
}

\author{
Tiziana Varenty ${ }^{1}$, Aidinil Zetra ${ }^{2}$, Zulfadli $^{3}$ \\ ${ }^{1}$ Jurusan Ilmu Politik, Fisip, Universitas Andalas, Email ; varentytiziana@gmail.com \\ ${ }^{2}$ Jurusan Ilmu Politik, Fisip, Universitas Andalas \\ ${ }^{3}$ Jurusan Ilmu Politik, Fisip, Universitas Andalas
}

\begin{abstract}
Abstrak
Dukcapil Kota Padang merupakan Instansi Pelaksana kebijakan Administrasi Kependudukan di Kota Padang. Berbagai kendala dan permasalahan tersebut tentu harus diidentifikasi agar di masa yang akan datang perbaikan dapat dilakukan dan tujuan utama kebijakan tersebut dapat dicapai. Penelitian ini menggunakan metode penelitian kualitatif dengan tipe deskriptif. Proses pengumpulan data dilakukan dengan mewawancarai informan kunci yang dianggap memahami permasalahan KTP-El serta melengkapinya dengan beberapa referensi tertulis seperti buku, koran, internet dan lain-lain. Hasil penelitian menunjukkan bahwa adanya kegagalan administratif, beberapa faktor utama yang masih menjadi kendala dalam pelaksanaan kebijakan KTP-El di Dukcapil Kota Padang adalah keterbatasan sarana dan prasarana, kurangnya koordinasi dan kerjasama di area internal Dukcapil Kota Padang, serta mimimnya komunikasi yang efektif dari pihak Dukcapil kepada masyarakat. Dari permasalahan yang ada, timbullah kesalahpahaman antara masyarakat dan pihak Dukcapil.
\end{abstract}

Kata Kunci: Kebijakan Publik ; Proses Kebijakan ; Evaluasi Kebijakan

\begin{abstract}
In Padang City Population and Civil Registration Agency of Padang City is the Implementing Agency for Population Administration policies in the City of Padang. Certain problems must be identified so that in the future it can be done and the main objectives can be achieved. This study uses qualitative research methods with descriptive types. The data process is carried out by interviewing key informants who are used to understand KTP-El and complete it with references such as books, newspapers, the internet and others. The results showed that there's an administrative failure where the main factors that were still affected the implementation of the KTPEl policy in Population and Civil Registration Agency Padang City were facilities and infrastructure, lack of cooperation and teamwork in the internal areas of Population and Civil Registration Agency Padang, as well as lack of effective communication from Population and Civil Registration Agency Padang to the community. From the existing factors, there was a misunderstanding between the community and the Population and Civil Registration Agency Padang party.
\end{abstract}

Keywords: Public Policy ; Policy Process ; Policy Evaluation

\section{PENDAhuluan}

Kebijakan Publik merupakan salah satu kajian dalam ilmu politik. Dari sudut pandang politik, kebijakan publik boleh jadi dianggap sebagai salah satu hasil dari perdebatan panjang yang terjadi di ranah negara dengan aktor-aktor yang mempunyai berbagai macam kepentingan. Dengan demikian, kebijakan publik tidak hanya dipelajari sebagai proses pembuatan kebijakan, tetapi juga dinamika yang terjadi ketika kebijakan tersebut dibuat dan dimplementasikan. Untuk itu, pemerintah dan masyarakat memiliki hak 
untuk mengetahui tidak hanya seberapa baik suatu kebijakan bekerja, tapi juga sejauh mana kebijakan itu sudah berjalan. Untuk menilai sejauh mana kebijakan sudah dikembangkan, evaluasi perlu dilaksanakan. William N.Dunn kemudian mengartikan secara spesifik Evaluasi kebijakan berkenaan dengan produksi informasi mengenai nilai atau manfaat hasil kebijakan. Definisi lain dikemukakan oleh Worthen dan Sanders, yaitu kegiatan mencari sesuatu yang berharga tentang sesuatu, termasuk mencari informasi yang bermanfaat dalam menilai suatu program, produksi, serta yang bermanfaat dalam menilai suatu program, produksi, prosedur, serta alternatif strategi yang diajukan untuk mencapai tujuan yang ditentukan. Pada tahap evaluasi, hasil evaluasi sangat berguna bagi pemerintah, terutama untuk menentukan apakah kebijakan atau program tersebut dapat dilanjutkan, dihapuskan, direvisi, atau dimodifikasi. Menurut Abdulkahar Badjuri dan Teguh Yuwono, evaluasi kebijakan setidak-tidaknya di maksudkan untuk memenuhi tiga tujuan utama, yaitu:

- Untuk menguji apakah kebijakan yang diimplementasikan telah mencapai tujuannya.

- Untuk menunjukkan akuntabilitas pelaksana publik terhadap kebijakan yang telah diimplementasikan.

- Untuk memberikan masukan pada kebijakan-kebijakan publik yang akan datang.

Sesungguhnya evaluasi kebijakan publik mempunyai empat lingkup makna, yaitu evaluasi kebijakan perumusan kebijakan, evaluasi implementasi kebijakan, evaluasi kinerja kebijakan, dan evaluasi lingkungan kebijakan. Sebagian besar pemahaman tentang evaluasi kebijakan publik berada pada domain ini. Hal ini bisa difahami, karena memang implementasi merupakan faktor penting dari kebijakan yang harus dilihat benar-benar.

Evaluasi implementasi kebijakan juga berkenan dengan kriteria "keberhasilan kebijakan". Patton \& Savicky (1993) mengemukakan empat jenis "kegagalan kebijakan", yaitu:

- The policy is formulated successfully, but the policy is unable to be implemented. It named as management failure, since policy then undermanage of unable-to-manage.

- The policy is formulated successfully, but the implementation is costly. It named as administrative failure.

- The policy is formulated successfully, the implementation is successful, but the result is not as the design. It named as design failure.

- The policy is formulated successfully, the implementation is as successful as the design, but it was fit to the policy wisdom of the hoped result. It named as theory failure. 
- The policy is formulated successfully, but in the implementation it is taken over by another political and/or administration interest, hence creates a totally different result. It named as derailed policy.

Berbagai kebijakan dan program pembangunan yang dirancang secara baik oleh pemerintah ketika diimplementasikan seringkali ternyata pencapaiannya jauh dari apa yang diharapkan. Fakta yang ada menunjukkan bahwa berbagai kondisi ideal yang tercantum di dalam dokumen kebijakan, misalnya: undang-undang, peraturan pemerintah, regulasi setingkat menteri, dan program pembangunan tahunan yang rutin ternyata ketika harus berhadapan dengan berbagai realitas di lapangan menjadi mandeg atau dengan kata lain sulit untuk direalisasikan. Berbagai faktor disinyalir menjadi penyebab kegagalan berbagai program pemerintah. Selain karena masalah Korupsi, Kolusi dan Nepotisme (KKN), variabel penjelas yang lain, seperti: adanya kecenderungan untuk penyeragaman kebijakan, lemahnya dukungan pemerintah daerah, dan rendahnya pengetahuan kelompok sasaran terhadap berbagai program yang di implementasikan juga merupakan kontributor terhadap kegagalan implementasi program-program tersebut.

Salah satu kebijakan yang menarik fenomenanya untuk disimak adalah pelaksanaan KTP-El (KTP Elektronik). Berdasarkan Pancasila dan Undang-Undang Dasar Negara Republik Indonesia Tahun 1945 pada hakikatnya Negara berkewajiban memberikan perlindungan dan pengakuan terhadap penentuan status pribadi dan status hukum atas setiap Peristiwa Kependudukan dan Peristiwa Penting yang dialami oleh Penduduk dan/atau Warga Negara Indonesia yang berada di luar wilayah Negara Kesatuan Republik Indonesia.

Namun, pada kenyataannya, banyak permasalahan yang timbul terkait pelaksanaan kebijakan KTP-El di Indonesia. Dalam sebuah penelitian mengenai registrasi kependudukan di Indonesia yang dipublikasikan oleh Smeru Research Institute pada tahun 2016, menemukan bahwa sistem registrasi penduduk di Indonesia masih lemah. Hal ini menyebabkan jutaan anak Indonesia tumbuh tanpa akte kelahiran sehingga mereka tidak dapat mendaftar sekolah. Hal ini juga menyebabkan jutaan penduduk usia 17 tahun ke atas tidak memiliki Kartu Tanda Penduduk (KTP) elektronik sehingga mereka tidak bisa menjadi anggota Badan Penyelenggara Jaminan Sosial (BPJS) Kesehatan. Ini berarti negara telah melakukan diskriminasi terhadap mereka. Bahkan penelitian ini merekomendasikan pemerintah untuk melakukan revisi ulang terhadap Undang-undang No. 24 Tahun 2013 tentang Perubahan Undang-undang No. 23 Tahun 2006 tentang Administrasi Kependudukan. Selain itu, adanya kasus korupsi KTP-El yang terjadi pada tingkat pusat juga mempengaruhi pelaksanaan tertib administrasi kependudukan yang dibuktikan dengan banyaknya masyarakat Indonesia yang tidak mendapatkan e-KTP. 
Salah satu fenomena yang menarik mengenai pelaksanaan KTP-El di daerah adalah, kasus pemanggilan Dukcapil dan Camat se-Kota Padang pada bulan Agustus 2017 lalu. Pemanggilan ini terkait dengan maladministrasi pelayanan dalam pembuatan KTP-El baik di tingkat Kecamatan maupun di Dukcapil Kota Padang. Dalam sebuah penelitian mengenai pelaksanaan kebijakan KTP-El di Kota Padang yang berjudul Implementasi Program KTP Elektronik (e-KTP) di Daerah Percontohan yang dilakukan oleh Roni Eka Putra dan Tengku Rika Valentina, yang dilakukan pada tahun 2011 menemukan bahwa masih belum maksimalnya pelaksanaan KTP-El di Kota Padang. Padahal Kota Padang adalah pilot project pelaksanaan KTP-El. Hal ini ditandai dengan masih belum tercapainya target yang ditentukan yaitu sebanyak 26.000 wajib KTP. Selain itu, permasalahan lain adalah minimnya koordinasi dengan SKPD lainnya dan tidak tersedianya Standard Operating Procedure (SOP) atau petunjuk pelaksanaan teknis.

Peneliti kemudian menemukan beberapa informasi positif mengenai beberapa pencapaian Dukcapil dalam menjalankan tugas sebagai instansi pelaksana administrasi kependudukan. Salah satunya adalah terpilihnya Dukcapil Kota Padang sebagai proyek percontohan (pilot project) pelayanan publik pada tahun 2015. Kemudian pada tahun 2016, Dukcapil Kota Padang juga berhasil mendapatkan piagam penghargaan dari Kementrian Dalam Negeri, berkat keberhasilan perekaman data KTP-El sebanyak $91 \%$ dari 600 ribu lebih jumlah penduduk wajib KTP. Dengan berbagai temuan di media massa ini, peneliti kemudian tertarik untuk menelisik lebih jauh mengenai pelayanan di Dukcapil Kota Padang.

Dalam bentuk dokumen resmi, dokumen yang berhasil didapatkan adalah hasil capaian kinerja Dukcapil Kota Padang pada tahun 2009 hingga 2013. Capaian kinerja ini dijelaskan dalam Renstra (Rencana Kerja Strategis) Dukcapil Kota Padang Tahun 20142019. Renstra ini peneliti dapatkan dari website www.ppid.padang.go.id. PPID adalah Pejabat Pegelola Infromasi Publik dan Dokumentasi yang bertugas untuk mempublikasikan Informasi Publik yang berkaitan dengan Badan Publik untuk masyarakat luas. Lebih lanjut, pencarian untuk mendapatkan dokumen terbaru mengenai Dukcapil dalam situs ini, tidak membuahkan hasil. Dokumen Renja (Rencana Kerja) yang di upload pada tahun 2018 kemudian tidak dapat diakses dan berakhir dengan halaman error pada situs tersebut. Berikut data target dan capaian kinerja Dukcapil Kota Padang tahun 2013:

\section{Tabel 1. Pencapaian Kinerja Pelayanan SKPD}

\begin{tabular}{llll}
\hline No & Indikator Kinerja Sasaran & Target 2013 & Capaian 2013 \\
1 & Penerbitan Kartu Tanda & & \\
& Penduduk (KTP) & &
\end{tabular}

-KTP Elektronik

723.122 


\begin{tabular}{llll}
\hline & -KTP Non Elektronik & 40.000 & 13.517 \\
2 & Penerbitan Kartu Keluarga & 50.000 & 30.467 \\
3 & Penerbitan Akta Catatan & 40.425 & - \\
\hline
\end{tabular}

Sumber: Renstra Dukcapil Kota Padang Tahun 2014-2019

Pada tabel 1.1 dapat dilihat angka capaian yang masih jauh dari target. Bahkan, beberapa informasi peneliti temukan dalam kondisi strip atau kosong. Lebih jauh, observasi kemudian dilakukan di Kantor Dinas Kependudukan dan Catatan Sipil Kota Padang, pada tanggal 13 hingga 15 Februari 2018. Temuan yang di dapati berupa beberapa masyarakat yang mengeluhkan pelayanan kependudukan di Dukcapil Kota Padang. Diantaranya adalah petugas yang tidak mampu memberikan kepastian penerbitan dokumen kependudukan, papan informasi persyaratan pelayanan yang minim, antrian pelayanan yang kurang efektif, hingga gedung kantor yang tidak memadai untuk menampung mobilitas pelayanan administrasi kependudukan Dalam kasus pelaporan masyarakat kepada Ombudsman Sumatera Barat, peneliti mendapatkan data rincian laporan masyarakat mengenai permasalahan KTP-El yang peneliti rangkum dalam tabel berikut ini:

Tabel 2. Daftar Laporan yang masuk ke Ombudsman dengan Terlapor Dukcapil Kota Padang Tahun 2016-2017

\begin{tabular}{l}
\hline \multicolumn{2}{c}{ Instansi Terlapor } \\
\hline Kepala Disdukcapil Kota Padang \\
\hline Kepala Dinas Kependudukan Dan Catatan \\
Sipil Kota Padang \\
\hline Dinas Kependudukan Dan Catatan Sipil Kota \\
Padang \\
\hline
\end{tabular}

Dalam rentang tahun 2016 hingga 2017 terdapat beberapa laporan masyarakat yang berkaitan dengan data kependudukan. Beberapa kasus di atas sudah ada yang selesai dan masih ada yang menunggu tindak lanjut dari Disdukcapil Kota Padang sendiri.

Salah satu yang menjadi perhatian peneliti dan menjadikan penelitian ini menjadi penting untuk dilakukan adalah, masih adanya permasalahan data ganda yang berpotensi menjadi permasalahan dalam Pilkada serentak di Kota Padang yang akan dilaksanakan pada tanggal 27 Juni 2018 mendatang. Padahal dalam implementasinya, KTP-El menerapkan Nomor Induk Kependudukan (NIK) yang merupakan nomor identitas penduduk yang bersifat unik atau khas, tunggal dan melekat pada seseorang yang terdaftar sebagai penduduk Indonesia, yang berlaku selamanya. Dalam SIAK, database antara kecamatan, kabupaten-kota, provinsi, dan Kementrian Dalam Negeri (Kemendagri) akan 
terhubung dan terintegrasi. Seseorang tidak bisa memiliki identitas ganda dengan adanya nomor identitas kependudukan (NIK). Sebab, nomor bersifat unik dan akan keluar secara otomatis ketika instansi pelaksana memasukkannya ke database kependudukan. Maka dari itu lahirlah pertanyaan penelitian, yaitu: Bagaimana Pelaksanaan KTP-El Pada Dinas Kependudukan dan Pencatatan Sipil Kota Padang? Adapun tujuan dari penelitian ini adalah: Untuk mengevaluasi pelaksanaan KTP-El pada Dinas Kependudukan dan Pencatatan Sipil Kota Padang.

\section{Kerangka Teori}

\section{Evaluasi Kebijakan}

William N. Dunn mengatakan evaluasi kebijakan adalah evaluasi yang berkenaan dengan produksi informasi nilai atau manfaat hasil kebijakan. Worthen dan Sander mendefinisikan evaluasi kebijakan yaitu kegiatan mencari sesuatu yang berharga tentang sesuatu, termasuk mencari informasi yang bermanfaat dalam menilai suatu program, produksi, prosedur, serta alternatif strategi yang diajukan untuk mencapai tujuan yang ditentukan.

Tujuan pokok dari evaluasi kebijakan bukanlah untuk menyalah-nyalahkan melainkan untuk melihat seberapa besar kesenjangan antara pencapaian dan harapan dari suatu kebijakan publik. Tugas selanjutnya adalah bagaimana mengurangi atau menutup kesenjangan tersebut. Jadi, evaluasi kebijakan publik harus difahami sebagai sesuatu yang bersifat positif. Evaluasi bertujuan untuk mencari kekurangan dan menutup kekurangan.

Abdulkahar Badjuri dan Yuwono, menyatakan setidak-tidaknya dimaksudkan untuk memenuhi tiga tujuan utama, yaitu: (1) untuk menguji apakah kebijakan yang diimplementasikan telah mencapai tujuannya; (2) untuk menunjukkan akuntabilitas pelaksana publik terhadap kebijakan yang telah diimplementasikan; (3) untuk memberikan masukan pada kebijakan-kebijakan publik yang akan datang. Sekalipun penerapan suatu kebijakan oleh pemerintah telah dirancang sedemikian rupa untuk mencapai tujuannya, namun tidak selalu penerapan tersebut dapat mewujudkan semua tujuan yang hendak dicapai. Terganggunya implementasi yang menjadikan tidak tercapainya tujuan kebijakan mungkin pula disebabkan oleh pengaruh dari berbagai kondisi lingkungan yang tidak teramalkan sebelumnya.

William N.Dunn kemudian mensarikan beberapa kriteria dalam evaluasi kebijakan. Kriteria untuk evaluasi diterapkan secara restrospektif (ex post). Kriteria ini dapat dilihat pada tabel dibawah ini. 
Tabel 3. Kriteria Evaluasi

\begin{tabular}{|c|c|c|}
\hline Tipe Kriteria & Pertanyaan & Ilustrasi \\
\hline Efektivitas & $\begin{array}{l}\text { Apakah hasil yang diinginkan } \\
\text { telah tercapai }\end{array}$ & $\begin{array}{l}\text { Unit } \\
\text { Pelayanan }\end{array}$ \\
\hline Efisiensi & $\begin{array}{l}\text { Seberapa banyak diperlukan untuk } \\
\text { mencapai hasil yang diinginkan? }\end{array}$ & $\begin{array}{l}\text { Rasio } \\
\text { baiaya- } \\
\text { manfaat }\end{array}$ \\
\hline Kecukupan & $\begin{array}{l}\text { Seberapa pencapaian hasil yang } \\
\text { diinginkan memecahkan masalah? }\end{array}$ & $\begin{array}{l}\text { Biaya tetap } \\
\text { efektivitas }\end{array}$ \\
\hline \multirow[t]{3}{*}{ Perataan } & \multirow{3}{*}{$\begin{array}{l}\text { Apakah biaya dan didistribusikan } \\
\text { dengan merata kepada kelompok- } \\
\text { kelompok yang berbeda? }\end{array}$} & $\begin{array}{l}\text { Kriteria } \\
\text { Pareto }\end{array}$ \\
\hline & & $\begin{array}{l}\text { Kriteria } \\
\text { Kaldor-Hicks }\end{array}$ \\
\hline & & $\begin{array}{l}\text { Kriteria } \\
\text { Rawls }\end{array}$ \\
\hline Responsivitas & $\begin{array}{l}\text { Apakah hasil kebijakan } \\
\text { memuaskan kebutuhan, preferensi } \\
\text { atau nilai kelompok-kelompok } \\
\text { tertentu? }\end{array}$ & $\begin{array}{l}\text { Konsistensi } \\
\text { dengan } \\
\text { survai warga } \\
\text { negara }\end{array}$ \\
\hline Ketepatan & $\begin{array}{l}\text { Apakah hasil (tujuan) yang } \\
\text { diinginkan benar-benar berguna } \\
\text { bernilai? }\end{array}$ & $\begin{array}{l}\text { Program } \\
\text { public harus } \\
\text { merata } \\
\text { efisien }\end{array}$ \\
\hline
\end{tabular}

Sumber: William N.Dunn, Pegantar Analisis Kebijakan Publik Edisi kedua, 2003

\section{METODE PENELITIAN}

Penelitian ini menggunakan pendekatan kualitatif dengan tipe penelitian deskriptif, yaitu sebuah tipe penelitian yang menggambarkan temuan sebuah fenomena sosial secara deskriptif. Bogdan dan Taylor menjelaskan bahwa penelitian kualitatif adalah prosedur penelitian yang menghasilkan data deskriptif berupa kata-kata tertulis atau lisan dari orangorang dan perilaku yang dapat diamati. Penelitian kualitatif bertujuan untuk memperoleh gambaran seutuhnya mengenai suatu hal menurut pandangan manusia yang menjadi obyek kajian (Nazir,1986)

\section{HASIL DAN PEMBAHASAN}

\section{Efektivitas}

Pada kriteria ini, akan melihat apakah kebijakan yang ada sudah mampu mencapai hasil yang diinginkan. Berdasarkan data temuan dokumen Laporan Akuntabilitas Kinerja Instansi Pemerintahan (LAKIP) Disdukcapil Kota Padang Tahun 2017, Disdukcapil Kota Padang sudah melakukan pelaksanaan penerbitan KTP-El dan mencapai target pada tahun 
2017. Dimana persentasenya mencapai $100 \%$. Resapan dana dalam kegiatan perekaman dan pencetakan KTP-El ini hingga Rp 314.278.000,-. Melalui keterangan Izmi Maylendra, selaku Kepala Seksi Identitas Penduduk di Disdukcapil Kota Padang, pencapaian tersebut merupakan suatu hal yang lumrah bagi Instansi Pelaksana. Berdasarkan dokumen Tim Penilai Dinas Kependudukan Kabupaten Kota Terbaik dalam Pelaksanaan Administrasi Kependudukan dan Pencatatan Sipil Sumatera Barat, yang diadakan pada tahun 2017 lalu, Disdukcapil Kota Padang tidak berhasil meraih posisi lima besar dalam penliaian tersebut. Pada indikator penilaian Kinerja dengan variabel penilaian Penyelesaian Perekaman dan Pencetakan KTP-El Sudah 100\%, Disdukcapil Kota Padang memperoleh nilai 7 dari penilaian maksimal 10. Temuan menarik lainnya adalah, munculnya kasus pelaporan Disdukcapil Kota Padang kepada Ombudsman Republik Indonesia perwakilan Sumatera Barat terkait pelaksanaan perekaman dan penerbitan KTP-El. Berdasarkan keterangan dari Asisten Ombudsman, Chairun Amalia terdapat setidaknya dua laporan dugaan Maladministrasi yang dilaporkan oleh masyarakat sepanjang tahun 2016. Namun, akhirnya laporan ditutup karena tercapainya kesepakatan diantara kedua belah pihak. Kedua laporan yang masuk kepada Ombudsman, berkaitan dengan dugaan penundaan penerbitan KTP-El oleh Disdukcapil Kota Padang.

\section{Efisiensi}

Kriteria efisiensi berkaitan dengan upaya yang diperlukan untuk mencapai hasil yang diinginkan dari sebuah kebijakan. Efisiensi juga dapat dikaitkan dengan inovasi yang dilakukan oleh pelaksana kebijakan untuk mencapai target yang di inginkan. Dalam hal ini, Disdukcapil Kota Padang melakukan beragam inovasi, salah satunya adalah program UP3SK (Unit Pelayanan Pendaftaran Penduduk dan Pencatatan Sipil Keliling). Sistem pelayanan UP3SK adalah pelayanan jemput bola dimana petugas Disdukcapil yang akan turun lapangan, mengunjungi masyarakat untuk memberikan pelayanan. Pelayanan UP3SK di Disdukcapil Kota Padang efektif terlaksana sejak tahun 2014. Pada operasionalnya, UP3SK dijalankan setiap hari Senin dan Kamis dengan sistem bergiliran ke setiap Kecamatan yang ada di Kota Padang. Tidak hanya itu, pada acara dan hari tertentu, UP3SK akan dioperasikan untuk menjangkau masyarakat secara lebih luas. Upaya-upaya yang dilakukan oleh pelaksana kebijakan dalam memaksimalkan kinerja kebijakan dapat memperbesar kemungkinan tercapainya target sebuah kebijakan. Upaya- upaya tersebut dapat menghasilkan inovasi- inovasi yang akan mempermudah akses pelayanan sehingga kebijakan dapat dilaksanakan dengan sukses. Keterbatasan sumber daya dalam pelaksanaan kebijakan, seharusnya dapat memotivasi pelaksana kebijakan untuk melahirkan inovasi untuk menghasilkan pelayanan yang prima. 


\section{Kecukupan}

Kriteria kecukupan berbicara tentang kecukupan Sumber Daya Manusia (SDM) serta peralatan dan perlengkapan juga mempengaruhi kinerja kebijakan. Kurang memadainya SDM serta perlengkapan/peralatan yang ada, akan berpengaruh terhadap hasil atau pencapaian kebijakan tersebut, dan berlaku sebaliknya. Masih dalam sesi wawancara yang sama dengan Izmi Maylendra, kekurangan SDM juga turut andil dalam pelaksanaan kebijakan KTP-El. Masih banyaknya pekerja outsourcing dinilai menjadi faktor karena kurangnya motivasi kerja. Edukasi atau pendidikan pegawai juga berperan dalam menentukan maksimalnya pelayanan yang diberikan kepada masyarakat. Selain sumber daya manusia, pada Dinas Kependudukan dan Pencatatan Sipil Kota Padang juga didukung oleh sarana dan prasarana perkantoran. Berdasarkan dokumen Rencana Kerja Strategis (RENSTRA) Disdukcapil Kota Padang tahun 2014-2019. Hal lain yang menjadi perhatian peneliti adalah, tidak fokusnya masing-masing informan dalam memberikan jawaban valid atas pertanyaan yang peneliti ajukan. Seperti pada wawancara dengan Ashardi Yandra selaku Kasi Inovasi Disdukcapil Kota Padang yang lebih banyak memberikan jawaban abu-abu pada setiap pertanyaan yang diajukan. Padahal pertanyaan yang diajukan sudah disesuaikan dengan porsi posisi dan jabatan beliau di Disdukcapil Kota Padang.

Namun, berdasarkan data dokumen Laporan Tim Penilai Kualitas Pelayanan dan Kinerka Dinas Kependudukan dan Capil Kab/Kota Se Sumatera Barat tahun 2017 lalu, beberapa variabel penilalian berkaitan dengan kecukupan peralatan dan sumber daya yang dimiliki oleh Disdukcapil Kota Padang masih cukup memprihatinkan. Seperti pada indikator standar pelayanan dengan variabel pengumuman mengenai SOP pelayanan dan penyediaan alur atau bagan pelayanan, yang hanya memperoleh nilai 3 dengan maksimal skor adalah 10 .

Kebijakan merupakan suatu alat yang digunakan oleh Pemerintah untuk memecahkan permasalahan di tengah kehidupan bermasyarakat. Dalam pemecahan masalah tersebut, ditentukan ditentukanlah target atau batas capaian yang diinginkan dari sebuah kebijakan, untuk mengidentifikasi apakah kebijakan yang dikeluarkan sudah tepat dalam mengatasi permasalahan yang ada atau tidak. Dari hasil atau target yang dicapai, pemerintah dapat melihat apakah kebutuhan masyarakat dapat terpenuhi dari diberlakukannya kebijakan tertentu.

\section{Perataan}

Kriteria perataan akan menyinggung permasalahan sosialiasi dari sebuah kebijakan kepada sasaran kebijakan, yaitu masyarakat. perataan kebijakan juga menjadi penting untuk dilakukan, agar masyarakat memperoleh pengetahuan mengenai kebijakan yang telah digulirkan atau diimplementasikan. Berdasarkan keterangan Ashardi Yandra, sosialisasi 
berkaitang dengan pelaksanaan KTP-El sudah dilakukan oleh Disdukcapil Kota Padang. Sosialisasi biasanya dilakukan 2 bulan sekali, dan dilaksanakan pada Instansi tertentu untuk memberikan edukasi kepada masyarakat perihal kebijakan KTP-El. Pihak Disdukcapil juga menerima undangan untuk memberikan edukasi perihal Sistem Informasi Administrasi Kependudukan, khususnya KTP-El di Kota Padang. Salah satu contoh bentuk sosialisasi yang diberikan oleh Ashardi adalah, kegiatan yang diadakan oleh Disdukcapil Kota Padang di Lapas Muaro Padang bulan Oktober 2018 lalu, dimana Disdukcapil diminta oleh pihak Lapas untuk memberikan edukasi kepada tahanan tentang pentingnya Sistem Informasi Administrasi Kependudukan. Karena, pada dasarnya, masyarakat apapun statusnya, memiliki hak yang sama di mata hukum untuk memiliki Identitas Kependudukan.

Hal yang kontradiktif disampaikan oleh pihak Ombudsman Sumatera Barat. Melalui Chairun Amalia sebagai Asisten Ombudsman Sumatera Barat, mereka berpendapat bahwa salah satu faktor masih minimnya sosialisasi yang dilakukan oleh Disdukcapil kepada masyarakat terkait pelayanan administrasi kependudukan. Dengan minimnya informasi yang diberikan oleh Disdukcapil Kota Padang, masyarakat menjadi bingung dengan proses pembuatan KTP-El. Sosialisasi tentu dibutuhkan dalam implementasi kebijakan. Distribusi informasi yang merata akan memberikan dampak yang signifikan dalam pelaksanaan sebuah kebijakan. Seringkali, kesalahpahaman yang terjadi antara masyarakat dan pelaksana kebijakan dikibatkan minimnya informasi yang ada. Sehingga, miskomunukasi sering terjadi dan menyebabkan gesekan antara masyarakat dan pelaksana kebijakan.

\section{Responsivitas}

Kriteria ini merupakan bentuk responsivitas instansi pelaksana dalam memberikan pelayanan administrasi kependudukan kepada masyarakat. Berdasarkan observasi yang dilakukan oleh peneliti di lapangan selama penelitian, pelayanan administrasi kependudukan di Disdukcapil Kota Padang sudah cukup responsif. Dalam merespon keluhan masyarakat terkait laporan yang masuk pada Ombudsman RI terkait dugaan maladministrasi pelayanan di Disdukcapil Kota Padang, pihak Disdukcapil Kota Padang merespon dengan cukup baik. Berdasarkan keterangan dari Maiyulnita selaku Kepala Bidang Pengelolaan Informasi Administrasi Kependudukan Disdukcapil Kota Padang Pada wawancara penelitian awal, beliau menjelaskan kurangnya informasi dan pengetahuan masyarakat terhadap pelayanan di Disdukcapil Kota Padang lah yang menjadi salah satu faktor timbulnya berbagai kesalahpahaman antara masyarakat dan Disdukcapil Kota Padang. Berdasarkan Lakip Disdcukapil Kota Padang, tingkat terselesaikannya pengaduan masyarakat terkait pelayanan kependudukan sudah terealisasi sebesar $90 \%$ dari target $100 \%$ pada tahun 2017. Hal ini merupakan hal yang cukup positif, mengingat keterbatasan fasilitas dan sdm yang dimiliki oleh Disdukcapil Kota Padang. 


\section{Ketepatan}

Kriteria ketepatan adalah kriteria tentang manfaat dari hasil kebijakan. Kriteria ini juga berkaitan dengan perubahan signifikan yang tercipta dari implementasi sebuah kebijakan. Melalui KTP-El, pemerintah berharap terselenggaranya tertib administrasi kependudukan. Berdasarkan keterangan dari Ashardi Yandra, saat ini Disdukcapil Kota Padang sudah mampu memperkecil tingkat data ganda yang sangat meresahkan. Peningkatan penuntasan data ganda di Kota Padang meningkat setiap tahunnya. Tertibnya administrasi kependudukan juga dapat dirasakan untuk kegiatan lainnya seperti Pilkada, sensus penduduk hingga mengurangi tingkat kejahatan.

Namun, karena masih minimnya sarana dan prasarana yang dimiliki oleh Disdukcapil Kota Padang, kesulitan masih dirasakan oleh masyarakat dalam pengurusan KTP-El khususnya di Disdukcapil Kota Padang. Penuntasan data ganda sudah dilakukan walaupun masih belum mencapai target. Selain itu tingkat tertib administrasi saat ini sudah cukup memuaskan mencapai $75 \%$ pada tahun 2017. Tentu masih butuh perbaikan kedepannya agar dokumen administrasi masyarakat menjadi lebih tertib. Namun begitu, Disdukcapil Kota Padang masih belum berhasil keluar sebagai pemenang dalam Penilaian Disdukcapil Se-Sumatera Barat yang diadakan pada tahun 2017.

Tabel 4. Hasil Penilaian Disdukcapil Se-Sumatera Barat tahun 2017

\begin{tabular}{|c|c|}
\hline Kab/Kota & Kategori Pemenang \\
\hline Kota Padang Panjang & Terbaik semua kategori \\
\hline Kabupaten Padang Pariaman & Terbaik kateogori Motivasi dan Manajerial \\
\hline Kota Bukittinggi & $\begin{array}{l}\text { Terbaik kategori Kenyamanan } \\
\text { Pelayanan }\end{array}$ \\
\hline Kabupaten Agam & $\begin{array}{l}\text { Terbaik kategori Kuantitas Pencapaian } \\
\text { Target Naisonal }\end{array}$ \\
\hline Kabupaten Tanah Datar & Terbaik kategori Kreasi dalam Berinovasi \\
\hline
\end{tabular}

Sumber: Laporan Pelaksanaan Kegiatan Penilaian Dinas Kependudukan Kabupaten Kota Terbaik dalam Pelaksanaan Administrasi Kependudukan dan Pencatatan Sipil tahun 2017

Hal ini membuktikan bahwa masih butuh banyak perbaikan kedepannya agar pelayanan administrasi kependudukan menjadi lebih mudah untuk diakses oleh masyarakat, khususnya di Disdukcapil Kota Padang. Tercapainya sebuah target kebijakan akan menentukan nilai atau manfaat dari kebijakan tersebut. Nilai tersebut tentu harus dapat dirasakan langsung oleh masyarakat sebagai sasaran kebijakan. Baik masyarakat maupun pemerintah harus mampu menujukkan tanggung jawab, akuntabilitas, dan responsibilitas yang tinggi sesuai dengan kapasitasnya masing-masing. 


\section{KESIMPULAN}

Berdasarkan hal diatas, dapat disimpulkan sebagai berikut:

Efektivitas, pada kategori ini peneliti menemukan bahwa Disdukcapil Kota Padang belum sepenuhnya memenuhi target penerbitan ktp-el di Kota Padang, khususnya pada tahun 2017. Hal ini dari ditemukannya ketidakcocokkan data yang peneliti peroleh seperti keterangan dari pihak Ombudsman, hasil dari tim penilai Diukcapil tingkat Provinsi Sumatera Barat pada tahun 2017 lalu, hingga hasil survey terkait penerbitan ktp-el pada usia sekolah wajib ktp.

Efisiensi, pada kategori ini Disdukcapil Kota Padang berinovasi dengan menghadirkan program UP3SK (Unit Pelayanan Pendaftaran Penduduk dan Pencatatan Sipil Keliling). Tetapi, yang harus digarisbawahi adalah, masih belum maksimalnya operasional dari program ini sehingga masyarakat masih cukup awam dengan program ini yang dikenal dengan Capil Keliling. Penggunaan social messenger seperti whatsapp sebagai media komunikasi antar SKPD juga dimaksimalkan oleh pihak Disdukcapil dalam pelaksanaan perekaman hingga penerbitan ktp-el.

Kecukupan, secara umum sarana dan prasarana di Dukcapil Kota Padang kurang memadai untuk melaksanakan kegiatan penerbitan KTP-El. Dengan mobilitas pelayanan yang cukup tinggi setiap harinya, maka fasilitas yang ada masih butuh perbaikan dan penambahan serta perhatian lebih.

Perataan, kategori ini berkaitan dengan sosialisasi atau distribusi informasi yang telah diberikan oleh Disdukcapil Kota Padang. Dari temuan yang ada serta keterangan pihak terkait, Disdukcapil Kota Padang perlu melakukan lebih banyak sosialisasi mengenai pentingnya dokumen kependudukan khususnya ktp-el. Pihak Disdukcapil Kota Padang juga harus lebih aktif dalam mengedukasi masyarakat khususnya pada anak sekolah wajib ktp perihal persyaratan serta proses penerbitan ktp-el.

Responsivitas, Disdukcapil Kota Padang sudah cukup responsif dalam melayani administrasi kependudukan masyarakat. Hal ini dibuktikan dari beberapa laporan yang diperoleh Ombudsman Sumatera Barat dimana banyak laporan sudah terselesaikan.

Ketepatan, pada output (keluaran) yang dihasilkan dari kebijakan ini adalah keberhasilan kebijakan ini dalam memberikan data yang akurat pada instansi lain yang membutuhkan data administrasi kependudukan. Dari data yang ditemukan, pihak Dukcapil telah mampu menyediakan akurasi data hingga $75 \%$ kepada Instansi lain yang bekerjasama dengan pihak Dukcapil. Berdasarkan data tersebut, dan wawancara dengan pihak terkait lainnya, maka ktp-el sudah merupakan kebijakan yang tepat dalam mengatasi permasalahan identitas penduduk. Walaupun masih membutuhkan perbaikan kedepannya. 


\section{DAFTAR PUSTAKA}

\section{Buku}

Badjuri, Abdulkahar dan Yuwono, Teguh. 2002. Kebijakan Publik Konsep dan Strategi. Semarang: Universitas Diponegoro

Denzin, Norman K dan Lincoln, Yvonna S. 2009. Handbook Of Qualitative Research. Yogyakarta: Pustaka Pelajar

Dunn, William N. 2003. Pengantar Analisis Kebijakan Publik Edisi Kedua. Yogyakarta: Gadjah Mada University Press

Dye, Thomas R. 1987. Understanding Public Policy. USA: Prentice-Hall, INC., Englewood Cliffs, NJ.

Ekha, Roni Putera, Tengku Rika Valentina. 2011. MIMBAR. No 2. Vol 28, 193-201

Herabudin. 2016. Studi Kebijakan Pemerintah Dari Filosofi Ke Implementasi. Bandung: Pustaka Setia

Howlett, Michael, M, Ramesh dan Xun Wu. 2015. Public Policy and Administration. No 3-4. Vol 30, 209-220.

Khan, Anisur Rahman. 2016. Journal of Community Positive Practices. No 3. Vol 16, 312.

Moelong, Lexy J. 2007. Metodologi Penelitian Kualitatif. Bandung: Rosdakarya.

Nasution. 1992. Metode Penelitian Naturalistik Kualitatif. Bandung: Tarsito

Nazir, Muhammad. 1986. Metode Penelitian. Bandung: Rosdakarya.

Nugroho, Riant. 2004. Kebijakan Publik: Formulasi, Implementasi, dan Evaluasi Edisi Ketiga. Jakarta: Elex Media Komputindo

Nugroho, Riant. 2002. Public Policy Edisi 5. Jakarta: PT Elex Media Komputindo

Purwanto. Erwan Agus, Sulistyastuti, Dyah Ratih. 2012. Implementasi Kebijakan Publik Konsep dan Aplikasinya Di Indonesia. Yogyakarta: Penerbit Gava Media

Sugiyono. 2006. Metode Penelitian Kuantitatif Kualitatif Dan R\&D. Bandung: Alfabeta.

Artikel, Rendra Catur. 2017. Layanan KTP Bermasalah: Ombdusman Sumbar Panggil Disdukcapil dan Camat Se- Kota Padang. 


\section{Berita}

(https://kumparan.com/rendra-catur/ombudsman-sumbar-panggil-kadis-dukcapil-kotapadang-dan-camat-se-kota-padang-layanan-ktp) diakses pada tanggal 17 Maret 2018.

Charlie. 2015. Tiga SKPD Di Kota Padang Jadi Pilot Project Pelayanan Publik. (https://minangkabaunews.com/artikel-6690-tiga-skpd-di-padang-jadi-pilot-projectpercontohan-pelayanan-publik.html) diakses pada tanggal 16 Oktober 2017.

GoSumbar.com. Capai Target KTP-El 91 Persen, Disdukcapil Kota Padang Diapresiasi Kemendagri.

(https://www.gosumbar.com/berita/baca/2016/03/15/capai-target-ktpel-91-persendisdukcapil-kota-padang-diapresiasikemendagri\#sthash.JzOlfDTY.uoheKiXJ.dpbs) diakses pada tanggal 16 Oktober 2017.

Ilsany, Leo. 2016. E-KTP Di Padang Amburadul, Ombudsman Geram. (https://hariankoranpadang.com/2016/09/01/e-ktp-di-padang-amburadulombudsman-geram/) diakses pada tanggal 17 Oktober 2017.

Movanita, Ambaranie Nadia Kemala. 2017.Tak Sekedar Rugikan Keuangan Negara, Korupsi E-Ktp Cederai Demokrasi.

(https://nasional.kompas.com/read/2017/04/02/16304531/tak.sekedar\%20.rugikan.keuanga n.negara.korupsi.e-ktp.dinilai.cederai.demokrasi) diakses pada tanggal 3 Maret 2018.

Situs PPID Kota Padang. (ppid.padang.go.id/home/profil) diakses pada tanggal 27 Februari 2018. 